ECONOMICS

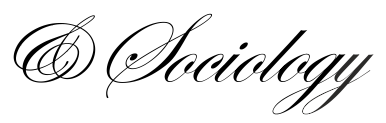

\author{
Beata Gavurova, \\ Technical University of Kosice, \\ Kosice, Slovakia, \\ E-mail:beata.gavurova@tuke.sk. \\ Eva Huculova, \\ Technical University of Kosice, \\ Kosice, Slovakia, \\ E-mail:eva.huculova@tuke.sk
}

\author{
Matus Kubak, \\ Technical University of Kosice, \\ Kosice, Slovakia, \\ E-mail:matus.kubak@tuke.sk
}

Martin Cepel,

LIGS University LLC,

Honolulu, Hawaii, USA

E-mail:cepel@benzinol.com

Received: February, 2017

1st Revision: March, 2017

Accepted: July, 2017

DOI: $10.14254 / 2071-$

789X.2017/10-3/15

JEL Classification: I21, I22, I25
Gavurova, B., Huculova, E., Kubak, M., Cepel, M. (2017). The State of Students'

Financial Literacy in Selected Slovak universities and its Relationship with Active Pension

Savings. Economics and Sociology, 10(3), 206-219. doi:10.14254/2071-789X.2017/10-3/15

\section{THE STATE OF STUDENTS' \\ FINANCIAL LITERACY IN SELECTED SLOVAK UNIVERSITIES AND ITS RELATIONSHIP WITH ACTIVE PENSION SAVINGS}

\begin{abstract}
The interest in retirement planning is increasingly brought to common people's attention due to demographic aging of population and better financial literacy level these days. In this study we analyze the level of financial literacy among Slovak university students in relation to further pension decisions and financial behavior overall. The primary aim of this research was to compare the level of financial literacy among the selected faculties of economics in Slovakia. The analytical part was oriented on evaluation of financial behavior of the respondents and their skills in terms of financial literacy concept along with the analysis of the correlative data dependence of the selected variables and their intensity by using the Logit model. At first, the results have shown a statistically significant dependency of financial literacy on the respondents' gender. Female respondents reached higher financial literacy than male ones. Older students did not achieve higher level of financial literacy as compared to younger students. Students do not look ahead and most of them do not calculate how much they need to save for their retirement. The results of the presented research provide important information for policy makers who should reflect on the present status of this issue in Slovakia.
\end{abstract}

Keywords: financial literacy, financial education, retirement planning, pension decision, Slovakia

\title{
Introduction
}

Financial literacy (FL) and its regulatory options are currently the subject of numerous professional and scientific discussions. Financially illiterates cannot fully participate in today's economy as such. It is important to develop students' skills in FL and strengthen the commitment of policy makers while introducing this topic into educational processes. In this context not only the demand increases particularly, but also the need for reliable data about FL among people worldwide. Such data can subsequently improve financial education strategies and implementation of financial education not only in schools. As a result of the impact of the economic and financial crisis accompanied with the process of demographic aging in all the economies of the world the question of the public pension systems' instability 
and threats to their sustainability is growing in importance (Rey-Ares et al., 2016). The shape of European age pyramid is transforming in consequence of higher life expectancy and consistently low birth rates what leads to a much older population structure. This unfavorable development is apparent in many European countries as well as in the United States. Between 2001 and 2016 the median age in Europe increased by 4.3 years, it means a rise from 38.3 years to 42.6 years (Eurostat, 2017). According to demographic projections by the Eurostat (2016) Slovak citizens will be aging among the fastest of all EU countries, whereas the average age of Slovak population increases by 4.6 years $(12.1 \%)$ over the period of 20072025. The aging index is likely to exceed the limit of 100 before 2025 . This means that the population of the post-productive age will be higher than the number of people in the preproductive age for the first time in history. The ratio of the elderly population to the working age population in Slovakia will be more than tripled (Rizman \& Harvan, 2015; Eurostat, 2016). Public expenditures being rather sensitive to the phenomenon of population aging will increase significantly by 2060 and will have a negative impact on the general government balance. Pensions and healthcare will be particularly responsible for expenditure growth. To meet the challenges of this ageing population, especially after the recent economic and financial crisis, standard ages for retirement have increased, and occupational pensions have become less generous. As a consequence, a substantial part of risks and responsibilities for adequate standards of living after retirement has been shifted from governments and employers onto individuals and/or private households (OECD, 2013; Oehler \& Werner, 2008; Prast \& Soest, 2016; Lusardi, 2015a; Lusardi, 2015b). In this context, the results of the research by Babiarz \& Robb (2014) pointed to the fact that households with greater financial knowledge and skills are more likely to be able to have emergency funds. The odds of having emergency savings could also increase with higher level of financial literacy. The research suggests the strong connectivity of FL with the accumulation of emergency savings which is a determining component of households' financial stability.

\section{Literature review}

In many foreign studies approaches that prefer rationality and pragmatic point of views in relation to FL are dominate. Consequently, higher financial knowledge helps individuals to monitor an optimal consumption and balanced portfolio of household with relation to finances (Romitiy \& Rossiz, 2014). They also lead to higher probability of savings' creation and correct financial planning for pension (Fernández-López et al., 2010; Hung et $a l .$, 2009). Relatively few EU adults save for old age and even those who save often have weak financial literacy (McGraw Hill Financial, 2015). The savings of individuals, especially students, must be adequate enough to cover longer retirement periods due to higher life expectancies (Lusardi, 2015a). Previous studies have established that planning for retirement has important implications for wealth accumulation and, thus, financial literacy appears to be positively strongly associated with retirement planning, particularly in terms of thinking about the financial resources needed for sustainable retirement. (Lusardi \& Mitchell, 2007a, 2007b; Prast \& Soest, 2016). Financial literacy may have a positive impact on other forms of financial behaviour what can lead to improvements of retirement resources, such as investing in the stock market (Prast \& Soest, 2016). Similar findings were observed by the authors Calvert et al. (2006), Lusardi \& Mitchell (2005), who suggested that sophisticated households disposing with financial skills and financial literacy are much more likely to buy stocks and invest more efficiently. In that sense, if students do not understand interest compounding, inflation, or risk diversification, they may be less likely to invest in complex assets such as equities or other securities. The experience gained in financial instruments and products also explain the relationship of investment knowledge with the rate of savings of individuals (Peng 
et al., 2007). Dutch authors Cox et al. (2015) showed in their study that financial literacy and risk aversion have considerable influence in deciding and choosing a mortgage. Given the fact that FL is low in many countries around the world and varies in different social and demographic characteristics, improving financial skills are particularly relevant in the current economic environment where people make a lot of financial decisions on a daily basis - from how much to save for retirement, insure income, finance housing, invest in financial market, etc. The question is whether individuals can rely on financial professionals in making these decisions. While financial literacy is shown to be generally low, in some studies from USA, Germany, and Netherlands most respondents give themselves much more higher scores when asked to assess their own financial knowledge in comparison with their actual attained scores of FL (Lusardi \& Tufano, 2009; Lusardi \& Mitchell, 2011; Bucher-Koenen et al., 2014). Therefore, many people may not even be aware of their low levels of knowledge and their potential need for financial advice. Individuals with low income and low educational attainment may not be able to afford the cost of financial professionals, even though they are likely to be the ones with lowest levels of financial literacy who need policy and education support (Lusardi, 2015b). Hanna \& Lindamood (2010) or other researchers (Grote, 2010; Winchester \& Huston, 2015) suggested that financial professionals provide advice and recommendations in all of financial or investment domains to help customers with increasing wealth, asset accumulation and also protecting their wealth. On the other hand, unfortunately, there can exist such type of advisors who may not always act in the best interest of their clients and consequently naive individuals may get poor advice. If aware of this, individuals may not ask for advice because they are afraid of the chance of not receiving relevant information from financial professionals (Calcagno \& Monticone, 2015; Debbich, 2015). In terms of financial literacy Belás et al. (2016) demonstrate that the intensity of interest in the socio-economic system is relatively low and students are not adequately motivated to be proactive in getting higher financial knowledge. In recent years, there are evident activities in a support of financial education especially from the European Commission (EC) side. The EC issued "The Communication on Financial Education" report. This report explicitly states economic and social advantages of a higher level of FL as well as fundamental principles of financial education control according to the chosen procedures (European Commission, 2007). The EC support led to implementation of various tools in a more complex financial world in order to increase FL of students. The FL standards represent one of those tools that are implemented in institutions of all levels of educational system, thus students may obtain higher financial skills (as for instance in the Czech Republic, where the National Strategy for Financial Literacy was issued in 2010). The primary platform is formed by economical categories, such as money and transactions, financial planning and management, risks and rewards, economic terms, consumer rights and responsibilities, etc., in spite of the differences in a content of educational standards in the individual countries (OECD, 2016). In Slovakia, the National Standard of FL (Version 1.0) was formed by the Ministry of Education, Science, Research and Sport of the Slovak Republic (MESRS) and actualized in 2013. Bank of financial literacy, Open-book of Financial Literacy, etc., were active in obtaining other resources (MESRS, 2014). The financial standards had there a dual role - they determined necessary knowledge, skills and experiences for educational staff and students, as well. Policy makers at the European level consider education and training essential to the development of modern knowledge society and economy (Minh \& Huu, 2016). Social welfare and global future growth will depend in particular on knowledge-intensive industries, investing in knowledge has become an important way to foster economic growth linking to creating new jobs in Europe countries (Dumciuviene, 2015). According to other researchers (Mak \& Braspenning, 2012; Rey-Ares et al., 2016) economic policy geared towards support of private retirement saving should take into consideration the social differences between population 
groups. For the most vulnerable groups with low income, low attained education and aged disadvantaged it would be advisable fostering educational programs to reduce financial illiteracy and amplify protection through regulation provided by financial institutions to prevent consumers from entering into overly risky agreements as well. Numerous research studies from abroad focus on process and result trajectories in the FL regulation within particular countries in recent years (Klapper et al., 2015; Rasoaisi \& Kalebe, 2015; Kozina \& Ponikvar, 2015; Nano \& Cani, 2016). Slovakia absents a complex research and expert studies within the given issue in spite of their importance in strategic concepts' formation, planning of educational processes, and also creating relevant policies. The given consequent fact represented a motivation for deeper research of this issue by research realization within chosen faculties in Slovakia.

\section{Methodological approach}

The survey of FL level was realized during the period from December 2015 to March 2016. Logit works from sample size bigger than 100 observations, thus it should be working in our case 496 students from three selected universities in Slovakia participated: Faculty of Economics, Technical University of Košice (EKF TUKE), Faculty of Management of University of Prešov in Prešov (FM PU) and Faculty of National Economy of the University of Economics in Bratislava (NHF EUBA). These Slovak universities have been active for many years and they provide various economically oriented study programs. They also realize research activities besides those educational ones. Table 1 shows a structure of research sample.

Table 1. Research sample according to sex and university level of respondents

\begin{tabular}{lccccccc}
\hline \multirow{2}{*}{$\begin{array}{l}\text { Faculty/ } \\
\text { University }\end{array}$} & \multicolumn{7}{c}{ Frequency of survey respondents } \\
\cline { 2 - 7 } & \multicolumn{1}{c}{ 1 $^{\text {st }}$ year of Bachelor study } & \multicolumn{2}{c}{$2^{\text {nd }}$ year of Master study } & Overall \\
\cline { 2 - 7 } & Men & Women & Total & Men & Women & Total & Frequency \\
\hline EKF TUKE & 46 & 89 & 135 & 33 & 60 & 93 & 228 \\
\hline FM PU & 18 & 39 & 57 & 11 & 25 & 36 & 93 \\
\hline NHF EUBA & 47 & 81 & 128 & 21 & 26 & 47 & 175 \\
\hline Total & 111 & 209 & 320 & 65 & 111 & 176 & 496 \\
\hline
\end{tabular}

Source: own processing.

The written form of survey by means of structured questionnaire that consisted of 54 questions was distributed in paper form and used in order to collect the necessary data. Questionnaire is available upon request from the corresponding author. Questionnaire structure was divided into three types of questions, so, it also considered key categories of a given issue. The first type of questions focused on demographic data of respondents and it included 6 questions in total, which focused on sex, age, place of residence, the highest educational attainment, present level of university degree and working condition. The second type of questions was related to practical tasks which focused on verifying the level of FL and confirming, and/or rejecting the hypothesis that emerges from prospect theory. The last type of questions consisted of those that concentrated on financial situation and financial behavior of a respondent. The survey questionnaire included closed questions that had either a character of multiple choice questions or questions with rating scales (7-10), when respondents could convey their attitudes. Rating questions were related to financial behavior of respondents, while focusing on their self-perception. The targets as well as character of a 
survey were determined by a form of questionnaire and questions' concept. The students' FL was evaluated by 7 specific and practical (mathematical) tasks with multiple choices and one correct answer on the basis of content point of view. In the research, there was applied a verified and internationally respected procedure, which has also been used by the Global Financial Literacy Excellence Center (GFLEC) at the Washington university in the U.S. (e.g. Lusardi \& Tufano, 2009). Financial literate person is that kind of respondent who answered correctly at least 4 practical queries, i.e. an absolute majority of these tasks, while evaluating FL. The research line was defined by six hypotheses:

H1: Level of respondents' FL connected to respondents' sex. The primary source of this hypothesis was a research made by an international study, PISA (2012, in cooperation with GFLEC). This research made a conclusion that male respondents are more frequently ranked at higher, but also lower levels of FL evaluation (wide variance of achieved FL level). Female respondents reached average results in this research. Our research primarily focused on a possibility of such differentiation between sexes in terms of FL in students of specific economic faculties in Slovakia.

H2: Level of respondents' FL defined as input students, which is connected to high school type. Many high school study programs offer different knowledge of FL. On the other hand, FL is inevitable in daily life of each individual who becomes a client, customer, debtor, creditor, etc. In this context, each individual should have a certain level of FL. The differences presumed by this hypothesis are of main interest of this research, while accepting a fact that only a part of population continues in the university studies.

H3: Level of FL is increased by completing economic study programs at the university. The individuals achieve the highest level of education by completing the university study programs also in economic field. It is estimated that those individuals who did not complete any economic study programs, or are at the beginning of such studies have significantly lower level of FL than those respondents who are about to complete their economic studies.

H4: Level of FL is increased by experience with advice from financial professional. Whereas knowledge of the financial products offered by financial institutions is not easy, we assume that the respondents who have completed consultations with financial experts acquired a varying extent of some financial advice and knowledge, which may be helpful in better understanding of the current financial problems of everyday life and can translate into better assessment on respondents' level of FL.

H5: Level of FL is increased by experience with credit products. Similarly to the previous hypothesis we assume that the individual's experience with credit and financial products of various financial institutions may result in a positive effect on the level of FL. When you use specific financial products you get to know them better in terms of information on possible ways of remuneration, reimbursement, alternative financing, the risk of inflation, etc., which can expand their financial knowledge.

H6: Level of FL is increased by experience with investment in stocks, bonds, mutual funds, or other securities. One of the many components of application of financial skills and their improvement is the possibility of investing in securities of different forms. When investing actively or passively an individual can understand compound interest, inflation risk or the impact of interest rates on selected types of investments and etc. This knowledge increases their level of FL. Those respondents who are actively interested in the topic areas of investment can enhance their level of financial skills. 


\section{Conducting research and results}

Through Practical tasks used in the survey questionnaire which enabled to evaluate the level of students' FL in selected economical faculties were thematically-oriented to financial skills and abilities of respondents in simple and complex interest rate, inflation, influence of interest rates on particular types of investments. We have run binary logistic regression. Binary logistic regression is a particular case of the generalized linear model. In binary logistic regression the dependent variable is binary, thus has a dichotomous nature. In binary logistic regression, dependent variable does not need to be normally distributed. Further, this method does not require a linear relationship between the dependent variable and the repressors. Moreover, this method has overcome many of the restrictive assumptions of linear regression. Binary logistic regression measures the odds of occurrence of studied phenomenon with probability $\pi$, against nonoccurrence of given phenomenon with probability $1-\pi$. The part of these two values represents the ratio of the chances that explained variable reaches one out of mentioned category (occurrence vs. nonoccurrence). The odds of occurrence of the phenomenon is given as following: $=\frac{\pi}{1-\pi}$. Then, the probability is expressed as $\pi=\frac{o d d s}{1+o d d s}$. As mentioned above, logistic regression is based on the general linear model, in which the asymmetry of values is removed by transformation of the model by natural logarithm. Logit is then defined as $\ln ($ odd $s)=\ln \left(\frac{\pi}{1-\pi}\right)$ with the domain $(-\infty ; \infty)$. Logit model is than can be expressed in its basic shape as:

$$
\ln \frac{\pi}{1-\pi}=\beta_{0}+\beta_{1} X_{1}+\beta_{2} X_{2}+\ldots+\beta_{k} X_{k}
$$

where $\beta_{0}, \beta_{1} \ldots, \beta_{k}$ are the parameters of the model and $\pi$ is the conditional mean value of the response variable (Řezanková, 2011). Logistic regression estimates the probability that the phenomenon occurs. We assume that the phenomenon occurs when the probability is higher than the chosen threshold called "cut point". Cut point is usually set to 0.5 . When this value is lower we assume that the phenomenon does not occur at all (Král' et al., 2009). See Explanatory variables for our model below Table 2.

The dependent variable in our analysis is the financial literacy, or financial illiteracy of students. Dependent variable takes value 1 in case when subject is financially literate and value 0 in case, when subjects is financially illiterate. The level of students' FL was evaluated by 7 specific and practical (mathematical) tasks with multiple choices and one correct answer intent on basic financial skills. Respondent is defined as financial literate, if answered correctly an absolute majority of task (at least 4 practical queries) aimed at FL. Our dataset consists of 496 observations, where 320 were females and 176 were males. Basic overview of our distribution of financial literacy within our dataset is presented in Table 2.

Table 2. Descriptive statistics, distribution of financial literacy

Financial illiterate Financial literate

\begin{tabular}{|c|c|c|}
\hline 1 & 2 & 3 \\
\hline \multicolumn{3}{|l|}{ Gender } \\
\hline Men & 45 & 150 \\
\hline Women & 147 & 219 \\
\hline \multicolumn{3}{|l|}{ Year of study } \\
\hline First year of Bachelor study & 144 & 176 \\
\hline Last year of Master study & 48 & 128 \\
\hline
\end{tabular}


INTERDISCIPLINARY APPROACH TO ECONOMICS AND SOCIOLOGY

\begin{tabular}{lcc}
\hline \multicolumn{1}{c}{1} & 2 & 3 \\
\hline Highest level of education attained & & 119 \\
\hline Grammar School & 86 & 48 \\
\hline Business Secondary School & 43 & 4 \\
\hline Hotel academy & 6 & 5 \\
\hline Secondary vocational school & 9 & 183 \\
\hline Experience with financial professional & 120 & 121 \\
\hline not asked for advice from a financial professional & 72 & 156 \\
\hline asked for advice from a financial professional & & 148 \\
\hline Experience with credit products & 86 & \\
\hline no experience with credit or financial products & 106 & 272 \\
\hline experience with credit or financial products & & 32 \\
\hline Experience of investment in securities & 169 & \\
\hline $\begin{array}{l}\text { not invest in stocks, bonds, mutual funds, or other } \\
\text { securities }\end{array}$ & 23 & \\
\hline invest in stocks, bonds, mutual funds, or other securities & & \\
\hline
\end{tabular}

Source: own processing.

Explanatory variables for our model are:

Gender

Education

Year of study

University

Financial professional

Credit product

Investment
Nominal variable reaching two categories: males and females.

Categorical variable acquiring four categories: Grammar School, Business Secondary School, Hotel academy, Secondary vocational school.

Categorical variable acquiring two values: first year of Bachelor study and last year of Master study at the university.

Categorical variable indicating in which institution one is studying. Here we consider three faculties: The Faculty of Economics at the Technical University of Kosice (EKF TUKE), The Faculty of National Economy at the University of Economics in Bratislava (NHF EUBA) and The Faculty of Management of University of Prešov in Prešov (FM PU). Binary variable with two possible outputs: no experience with financial adviser, some experience with financial adviser. Binary variable with two possible outputs: no experiences with credit products, some experiences with credit products. Binary variable with two possible outputs: no experience with investing in securities, some experiences with investing in securities.

Table 3. Binary logistic regression

\begin{tabular}{lcccccc}
\hline \multicolumn{1}{c}{1} & B & S.E. & Wald & df & Sig. & Exp (B) \\
\hline \multicolumn{1}{c}{} & 2 & 3 & 4 & 5 & 6 & 7 \\
\hline Gender (males) & -.453 & .200 & 5.160 & 1 & .023 & .635 \\
\hline Education & & & 2.594 & 4 & .628 & \\
\hline Business Secondary School & .434 & .285 & 2.312 & 1 & .128 & 1.543 \\
\hline Hotel academy & .307 & .745 & .171 & 1 & .680 & 1.360 \\
\hline Secondary vocational school & -.118 & .584 & .041 & 1 & .840 & .889 \\
\hline $\begin{array}{l}\text { Year of study (last year of } \\
\text { Master study) }\end{array}$ & -21.967 & 40207.705 & .000 & 1 & 1.000 & .000 \\
\hline University & & & .891 & 2 & .641 & \\
\hline
\end{tabular}


INTERDISCIPLINARY APPROACH TO ECONOMICS AND SOCIOLOGY

\begin{tabular}{lcccccc}
\hline \multicolumn{1}{c}{1} & 2 & 3 & 4 & 5 & 6 & 7 \\
\hline NHF EUBA & -.075 & .277 & .073 & 1 & .787 & .928 \\
\hline FM PU & -.205 & .218 & .886 & 1 & .346 & .814 \\
\hline $\begin{array}{l}\text { Financial professional (some } \\
\text { experience with financial } \\
\text { adviser) }\end{array}$ & .156 & .202 & .601 & 1 & .438 & 1.169 \\
$\begin{array}{l}\text { Credit product (some } \\
\text { experience with credit } \\
\text { products) }\end{array}$ & -.316 & .191 & 2.744 & 1 & .098 & .729 \\
$\begin{array}{l}\text { Investment (some experience } \\
\text { of investing in securities) }\end{array}$ & .018 & .316 & .003 & 1 & .955 & 1.018 \\
\hline Constant & 22.790 & 40207.705 & .000 & 1 & 1.000 & $7.900 \mathrm{E} 9$ \\
\hline
\end{tabular}

Source: own processing.

T tests are in column Sig, R squared has very weak informative value in Logit models. Results of logistic regression are presented in Table 3. Model as a whole is statistically significant on the significance level 0.1 (see Table 4).

Table 4. Omnibus Tests of Model Coefficients

\begin{tabular}{lccc}
\hline & Chi-square & df & Sig. \\
\hline Step & 11.380 & 7 & 0.1 \\
\cline { 2 - 4 } Block & 11.380 & 7 & 0.1 \\
Model & 11.380 & 7 & 0.1 \\
\hline
\end{tabular}

Source: own processing.

The overall percentage of cases that are correctly predicted by the model is $63.1 \%$ (see Table 5).

Table 5. Classification table

\begin{tabular}{|c|c|c|c|c|c|}
\hline \multirow{3}{*}{\multicolumn{2}{|c|}{ Observed }} & & \multicolumn{3}{|c|}{ Predicted } \\
\hline & & & \multicolumn{2}{|c|}{ Financial literacy } & \multirow[b]{2}{*}{$\begin{array}{c}\text { Percentage } \\
\text { Correct }\end{array}$} \\
\hline & & & $\begin{array}{c}\text { financially } \\
\text { illiterate }\end{array}$ & $\begin{array}{c}\text { financially } \\
\text { literate }\end{array}$ & \\
\hline \multirow{3}{*}{ Step 1} & Financial & financially illiterate & 22 & 170 & 11.5 \\
\hline & literacy & financially literate & 19 & 285 & 93.8 \\
\hline & Overall $P$ & & & & 63.1 \\
\hline
\end{tabular}

a. The cut value is .500 .

Table 3 indicates, that the expected variable is Gender and Credit product - no other variable has a statistically significant impact on financial literacy of our sample. As far as variable Gender is concerned, the conclusion of our analysis is that being a male diminish the odds of being financially literate by $34.5 \%$ compared to females, and while controlling for other variables in the regression. Second statistically significant variable is Credit product (some experience with credit products). This variable is significant on $\alpha=0.1$ and we obtained some confusing finding. Concerning Credit product, the conclusion is following: once one has some experiences with credit products, this fact diminishes the odds of being financially literate by $27.1 \%$ compared to those, who have no experiences with credit products. The total share of the financial literacy of all students on the surveyed faculties who have confirmed 
experience with credit products is $48.67 \%$. On the contrary, the overall proportion of illiterate students who are already interested in credit products, but were unable to properly resolve most financial problems in the questionnaire, was $55.21 \%$.

The studied model as a whole defined gender as a statistically significant variable. Concerning compound interest and risk diversification, men of all respondents in our survey are less likely to respond correctly to the question compared to women. Generally, fewer men at all three Slovak economic faculties can answer all questions correctly compared to women. But, for instance, if we look deeper on students at EKF TUKE, male students of this faculty achieve higher level of FL than female students. For instance, where only $10.13 \%$ of male respondents are financially illiterate, while this number is in female respondents much higher, $30.87 \%$. Interestingly the analysis does not prove statistically significant dependence (pvalue $>0,05$ ) of year of study between the first year undergraduates and those graduates who are in the final year of their studies. Comparison of levels of financial literacy as a whole at both input and output achieved comparable worth. Although the results of binary logistic regression showed no significance of this variable throughout the study sample, among the faculties themselves included in the questionnaire we can find certain differences. A frequency rate of financially illiterate students from EKF TUKE was lower at the end of their studies $(9.68 \%)$ as at the beginning of their studies (33.33\%). Similar connection was found out at NHF EUBA, where a rate of financially literate students of the first year $(53.13 \%)$ was lower than in students of the last year at particular faculty (72.34\%). Logical connection was found in two universities, in Košice and Bratislava, while analyzing the relation between FL level of respondents and level of their studies at the university. In both cases, the statistically significant dependency was confirmed ( $\mathrm{p}$-value $<0.05$ ), which means that financial knowledge depends on completed level of study at particular university. However, this validity was not confirmed at FM PU (p-value $>0,05$ ), where the rate of financially literate first-year students at FM PU forms $31.58 \%$, while $27.78 \%$ of the last year students are financially literate. Business Secondary School in comparison to Grammar School, or other types of high schools teach many subjects of economy and they provide primary or broadened knowledge of finances and economy for their students. Therefore, it was supposed that respondents who attended Business Secondary School would reach a higher level of FL. The second one of interesting findings was the rejection of this hypothesis - we do not recognize any statistically significant dependency.

In our survey we asked respondents (age 19-25) whether they ever tried to figure out how much they need to save for retirement in the future. Up to $73.19 \%$ of students (363 from 496) reported that they have not think about the financing of their pensions yet, so, they have not sought any information on retirement planning yet. Less than one third of the sample students $(26.81 \%)$ indicated that they actually attempted to do a retirement saving calculation. The declared results showed that the majority of students on the analyzed faculties do not yet have a substantial idea of what the amount of their pensions will be. Since the saving of funds for retirement is a long process dependent on savings strategies, the pension savings themselves should be long-term and regular, because only in that case could be the saver progressive in investment strategies and only in that case could he achieve adequate recovery (Cenker, 2017). Individuals with poor financial skills may not realize the impending risks; they could underestimate the financial security in case of unforeseen circumstances, which could subsequently create problems with the appropriate management of monthly budget that could be eventually important in ensuring of individual's or household's better financial conditions. Early communication of this issue with young people is therefore a key way to improve the economic potential of individuals in the context of planning finances until reaching retirement age. It is also very important to present limitations of the Slovak survey besides the given comparable limitations of the research. One of research limits was the lower 
proportion of respondents in the sample. The second one was the uneven representation of respondents at researched faculties. Three selected faculties of economy were examined due to procedural and technical difficulties of a given survey. This focus limits the outputs' generalization of the whole Slovak population.

\subsection{Discussion}

This study deals with analysis and evaluation of current FL level of students at economic faculties. The FL was researched from the following point of views: different gender, the highest level of present attained education, completion of given study program, obtained experience with credit products, financial professional and investment in stocks. These factors represented a core of this research also in other authors from different countries. There was evident statistically significant dependency in researching FL of students in terms of gender. This dependency proved that female respondents had higher financial knowledge than male respondents. Controversial difference in FL, in terms of gender, where a probability that women answered the questions of FL correctly was lower, was presented by authors of foreign studies (Bottazzi \& Lusardi, 2016; Bucher-Koenen et al., 2014; van Rooij et al., 2011; Prast \& Soest, 2016; Lusardi \& Mitchell, 2005; Lusardi, 2008). Furthermore, we have found that there is a negative relationship with credit products experience and the likelihood of lower-level FL among students. The opposite result was recorded in the study by West et al. (2013), who recorded a significantly higher probability of credit card ownership by financially more literate respondents. Respondents with poor financial literacy compared with financially literate use reward credit cards up to $50 \%$ less. In this case, there is a risk where producers of financial products are able to exploit deficiencies in financial literacy to sell higher-priced consumer credit products. Dependency in relationship between FL and year of study was not evident in Slovak university students. Students in their last year of studies that focus on economy, or financial processes have no significantly higher level of FL than those students who did not complete these kinds of studies, or they are at the beginning of their studies. It means that financial knowledge does not depend on attained level of study at the university. Financial advisors have the ability to help individuals or households avoid making financial mistakes as well as aiding those who lack financial skills (Winchester \& Huston, 2015; Bluethgen et al., 2008) and the positive relationship between financial literacy and the use of financial advisors documented by Collins (2012), Calcagno \& Monticone (2015), and Debbich (2015) assume that financial literacy and financial advice are complements rather than substitutes. In this context, the research of Belás \& Gabčová (2016) confirmed the significant relation between customer satisfaction and customer loyalty and between customer loyalty and additional purchases potential of a client. Following our research, only a small proportion of the Slovak university students rely on advices from financial professionals and those with low financial literacy rely mostly on family and friends, at which results are consistent with van Rooij et al. (2011). Low levels of risk literacy may not only endanger the well-being of families and household stability but also the strength and stability of the macro economy (Lusardi, 2015b). Lusardi (2003) investigated that those who plan, accumulate more wealth before retirement and are more likely to invest in stocks or other securities in financial market. It means that if financial illiteracy leads to poor planning, it may also affect wealth accumulation. One of the reason people fail to plan for retirement, may be because they are financially illiterate (Lusardi \& Mitchell, 2005). The majority of people have a problem answering questions related on compoud interest, inflation or diversification as well as university students in our sample and most of them do not tend to plan financial resources for retirement (Prast \& Soest, 2016). Our results confirm a lack of retirement planning between Slovak students, which it is also consistent with work by Lusardi \& Mitchell (2005). Financial 
knowledge and planning are clearly interrelated, and keeping track of spending and budgeting appears conducive retirement saving. (Lusardi \& Mitchell, 2005). Using the responses of students to our survey we argue that lack of financial literacy can be crucial because they could have important consequences for lifetime wellbeing. According to a recent study of Totenhagen et al. (2015), generally, financial education for youth is essential for long-term fiscal well-being of individuals, families and our nation as a whole. FL should be translated in education of secondary school students to support management of their personal finances which may lead to higher preconditions for successful and quality life. In this sense it is also appropriate to focus on the use of modern methods that promote creativity and initiative of students (Belás et al., 2016).

\section{Conclusion}

Financial literacy is particularly an essential skill for young people, because nowadays students face financial decisions that can have crucial life-long consequences with impact on their retirement. Therefore, FL belongs to important qualities of an individual that help $\mathrm{him} / \mathrm{her}$ in adequate financial decision-making in regular financial situations. FL and its development improve in younger generation. Its level is different in various countries. The principal aim of this study was a comparison of FL within chosen economic faculties in Slovakia. The analysis focuses on FL comparison at "input and output" level, i.e. between first-year and last-year students of relevant study programs from procedural point of view. The written form of questionnaire was chosen due to given research targets and form of data collection. Many facts were found out by realizing survey, while using questionnaire that focused on financial behavior and respondents' skills of selected economic faculties. The analysis confirmed a substantial gender disparity in score points of FL, where fewer men can understand finance compared to women. There also exists a dependence of lower FL with growing experience with credit products. The majority of students in the sample indicated that they actually have not attempted to do a retirement saving calculation. Students do not look ahead and most of them do not calculate how much they need to save for retirement yet. On the other hand, planning for retirement has not to be a current issue because students rely on their workplace pension plan together with the governmental one. Financial and pension skills can not to be enough to guarantee optimal and effective pension decisions but on the other hand financial and pension literacy can help individuals to improve or insure sufficient retirement in a large extent. The results of presented research provide important information for policy makers who should reflect on present status of this issue in Slovakia, reveal research potential in adjusting FL monitoring system within Slovakia and develop a platform for efficient concepts of financial education in Slovakia. Such support of financial education may lead to higher individual financial literacy and in this manner improve pension literacy pension decisions of students. Last but not least, research initiation in FL area and its support from state will also support formation of international comparison platform and development of international standards in financial education field.

\section{Acknowledgement}

Research presented in this paper was supported by VEGA 1/0726/14.

\section{References}

Babiarz, P., \& Robb, C. A. (2014). Financial Literacy and Emergency Saving. Journal of Family and Economic Issues, 35(1), 40-50. doi:10.1007/s 10834-013-9369-9. 
Belás, J., \& Gabčová, L. (2016). The Relationship among Customer Satisfaction, Loyalty and Financial Performance of Commercial Banks. Ekonomie a Management, 19(1), 132147. doi:10.15240/tul/001/2016-1-010.

Belás, J., Nguyen, A., Smrčka, L., Kolembus, J., \& Cipovová, E. (2016). Financial literacy of secondary school students. Case study from the Czech Republic. Economics \& Sociology, 9(4), 191-206. doi:10.14254/2071-789X.2016/9-4/12

Bluethgen, R., Gintschel, A., Hackethal, A., \& Muller, A. (2008). Financial advice and individual investors' portfolios, 2-6. http://dx.doi.org/10.2139/ssrn.968197

Bottazzi, L., Lusardi, A. (2016). Gender Differences in Financial Literacy: Evidence from PISA Data in Italy. Retrieved Januay 11, 2017, from http://www.gltfoundation.com/en/differenze-di-genere-nelleducazione-finanziaria-idati-di-pisa-program-for-international-student-assessment-english-paper/

Bucher-Koenen, T., Lusardi, A., Alessie, R., \&Rooij, M. (2014). How financially literate are women? An overview and new insights (NBER Working Paper 20793). Cambridge, MA: National Bureau of Economic Research. Retrieved November 5, 2016, from http://www.nber.org/papers/w20793.

Calcagno, R., \&Monticone C. (2015). Financial literacy and the demand for financial advice. $J$ Bank Financ, 50, 363-380.

Calvert, L., Campbell, J. \& Sodini, P. (2006). Down or Out: Assessing the Welfare Costs of Household Investment Mistakes. Harvard University Working Paper. doi:10.3386/w12030.

Cenker, J. (2017). Prečo je dôchodok pre mladých dôležitý? Retrieved January 14, 2016, http://www.teraz.sk/ekonomika/video-preco-je-dochodok-pre-mladych/237840clanok.html.

Collins, J. M. (2012). Financial advice: a substitute for financial literacy? Financial Services Review, 21(4), 307-322. http://dx.doi.org/10.2139/ssrn.2046227.

Cox, R., Brounen, D., \& Neuteboom, P. (2015). Financial Literacy, Risk Aversion and Choice of Mortgage Type by Households. The Journal of Real Estate Finance and Economics, 50(1), 74-112. doi: 10.1007/s11146-013-9453-9.

Debbich, M. (2015). Why financial advice cannot substitute or financial literacy? Bank of France Working Paper No. 534.

Dumciuviene, D. (2015). The Impact of Education Policy to Country Economic Development. Procedia - Social and Behavioral Sciences, 191(2), 2427-2436. http://dx.doi.org/10.1016/j.sbspro.2015.04.302.

Fernández-López, S., Otero, L., Vivel, M., \& Rodeiro, D. (2010). What Are the Driving Forces of Individuals' Retirement Savings? Finance a uver - Czech Journal of Economics and Finance, 60(3), 226-251.

http://econpapers.repec.org/article/faufauart/v_3a60_3ay_3a2010_3ai_3a3_3ap_3a226251.htm.

Eurostat (2016). Population structure and ageing. Retrieved January 11, 2017, from http://ec.europa.eu/eurostat/statistics-

explained/index.php/Population_structure_and_ageing

Eurostat (2017). Population structure and ageing. Retrieved August 3, 2017, from http://ec.europa.eu/eurostat/statisticsexplained/index.php/Population_structure_and_ageing

Grote, J. (2010). How to build a niche practice. Journal of Financial Planning, 23(8), 24-29.

Hanna, S., \& Lindamood, S. (2010). Quantifying the economic benefits of personal financial planning. Proceedings of the Academy of Financial Services, 19(2). 
Hung, A. A, Parker, A. M., \& Yoong, J. (2009). Defining and Measuring Financial Literacy (RAND Working paper WR-708). Social Science Research Network. Retrieved September 8, 2016, from http://dx.doi.org/10.2139/ssrn.1498674.

Klapper, L., Lusardi, A., \& Oudheusden, P. (2015). Financial Literacy Around the World: Insights from the Standard \& Poor's ratings services global financial literacy survay. Retrieved December 11, 2015, from https://www.mhfi.com/corporateresponsibility/global-financial-literacy-survey.

Kozina, F. L., \& Ponikvar, N. (2015). Financial Literacy of First-Year University Students: The Role of Education. International Journal of Management, Knowledge and Learning, 4(2), 241-255. http://www.issbs.si/press/ISSN/2232-5697/4_241-255.pdf.

Král', P. et al. (2009). Viacrozmerné štatistické metódy so zameraním na riešenie problémov ekonomickej praxe. Banská Bystrica: Faculty of Economics Matej Bel University.

Lusardi, A. (2003). Planning and Saving for Retirement. Dartmouth College Working Paper. Retrieved January 14, 2017, from http://dartmouth.edu/search/gss/Planning\%20and\%20Saving\%20for\%20Retirement

Lusardi, A. (2008). Household Saving Behavior: The Role of Financial Literacy, Information, and Financial Education Programs (NBER Working Paper 13824). Cambridge, MA: National Bureau of Economic Research. Retrieved November 5, 2016, from http://www.nber.org/papers/w13824.

Lusardi, A. (2015a). Financial Literacy Skills for the 21st Century: Evidence from PISA. The Journal of Consumer Affairs, 49(3), 639-659. doi: 10.1111/joca.12099.

Lusardi, A. (2015b). Risk Literacy. Italian Economic Journal, 1(1), 5-23. doi:10.1007/s40797-015-0011-x.

Lusardi, A., \& Mitchell, O. S. (2005). Implications for Retirement Wellbeing of Financial Literacy and Planning. Pension Research Council WP 2010-26. Retrieved January 18, 2017, from https://ssrn.com/abstract=1695146 or http://dx.doi.org/10.2139/ssrn.1695146

Lusardi, A., \& Olivia S. M. (2007a). Baby Boomer Retirement Security: The Roles of Planning, Financial Literacy, and Housing Wealth. Journal of Monetary Economics, 54(1), 205-224.

Lusardi, A., \& Olivia S. Mitchell (2007b). Financial Literacy and Retirement Planning: New Evidence from the RAND American Life Panel. WP 2007-157. Retrieved January 9, 2017, fromhttps://ideas.repec.org/p/mrr/papers/wp157.html.

Lusardi A., \& Mitchell O. S. (2011). Financial literacy and retirement planning in the United States. Journal of Pension Economics and Finance, 10(4), 509-525. doi:10.3386/w17108.

Lusardi, A. \& Tufano, P. (2009). Debt Literacy, Financial Experiences, and Overindebtedness (NBER Working Paper 14808). Cambridge, MA: National Bureau of Economic Research. Retrieved October 20, 2016, from http://www.nber.org/papers/w14808.

Mak, V., \& Braspenning, J. (2012). Errare humanum est: Financial Literacy in European Consumer Credit Law. Journal of Consumer Policy, 35(3), 307-332. doi:10.1007/s10603-012-9198-5.

McGraw Hill Financial (2015). Global Financial Literacy. Retrieved September 9, 2015, from https://www.mhfi.com/corporate-responsibility/global-financial-literacysurvey?keyfindings.

Ministry of Education, Science, Research and Sport of the Slovak Republic (2014). Národný štandard finančnej gramotnosti verzia 1.1. Retrieved August 8, 2015, from: https://www.minedu.sk/narodny-standard-financnej-gramotnosti-verzia-11/. 
Minh, N. V., \& Huu, H. N. (2016). The Relationship between Service Quality, Customer Satisfaction and Customer Loyalty: An Investigation in Vietnamese Retail Banking Sector. Journal of Competitiveness, 8(2), 103-116.

Nano, D., \& Cani, S. (2016). The Differences in Students' Financial Literacy based on Financial Education. Academicus - International Scientific Journal, 2013(8), 149-160. doi:10.7910/DVN/4WU8KP.

OECD (2013). Pensions at a Glance 2013: OECD and G20 Indicators, OECD, Paris.

Oehler, A., \& Werner, Ch. (2008). Saving for Retirement - A Case for Financial Education in Germany and UK? An Economic Perspective. Journal of Consumer Policy, 31(3), 253283.

Peng, T. M., Bartholomae, S., Fox, J. J., \& Cravener, G. (2007). The Impact of Personal Finance Education Delivered in High School and College Courses. Journal of Family and Economic Issues, 28(2), 265-284. doi:10.1007/s10834-007-9058-7.

Prast, H. M. \& Soest, A. (2016). Financial Literacy and Preparation for Retirement. Intereconomics, 51(3), 113-118. doi:10.1007/s10272-016-0588-9.

Rasoaisi, L., \& Kalebe, K. M. (2015). Determinants of financial literacy among The National University of Lesotho students. Asian Economic and Financial Review, 5(9), 10501060. doi:10.18488/journal.aefr/2015.5.9/102.9.1050.1060.

Řezanková, H. (2011). Analýza dat z dotaznikových šetrení. $3^{\text {rd }}$ ed. Praha: Professional Publishing.

Rey-Ares, L., Fernández-López, S. \& Vivel-Búa, M. (2016). The Influence of Social Models on Retirement Savings: Evidence for European Countries. Social Indicators Research, 1-22. doi:10.1007/s11205-016-1533-9.

Romitiy, A., \& Rossiz, M. (2014). Wealth decumulation, portfolio composition and financial literacy among European elderly (Working paper 375). Carlo Alberto Notebooks. Retrieved November 2, 2016, from http://www.carloalberto.org/research/workingpapers/2014.

Rizman, T., \& Harvan, P. (2015). Rýchlo starnúce Slovensko. Retrieved January 9, 2017, from http://www.finance.gov.sk/Default.aspx?CatID=10181

Totenhagen, C. J., Casper, D. M., Faber, K. M., Bosch, L. A., Bracamonte Wiggs, C., \& Borden, L. M. (2015). Youth Financial Literacy: A Review of Key Considerations and Promising Delivery Methods. Journal of Family and Economic Issues, 36(2), 167-191. doi:10.1007/s10834-014-9397-0.

van Rooij, M., Lusardi A., \& Rob, A. (2011). Financial literacy and stock market participation. Journal of Financial Economics, 101(2), 449-472.

West, J., Drew, M., Bianchi, R., \& Walk. A. (2013). Financial product complexity and the limits of financial literacy: A special issue of the Journal of Financial Services Marketing. Journal of Financial Services Marketing, 18(3), 153-157. doi:10.1057/fsm.2013.19.

Winchester, D. D., \& Huston, S. J. (2015). All Financial Advice for the Middle Class is Not Equal. Journal of Consumer Policy, 38(3), 247-264. doi:10.1007/s10603-015-9290-8. 